\title{
OPEN Author Correction: Combination of anti-vascular agent - DMXAA and HIF-1 $\alpha$ inhibitor - digoxin inhibits the growth of melanoma tumors
}

\section{Ryszard Smolarczyk, Tomasz Cichoń, Ewelina Pilny, Magdalena Jarosz-Biej, Aleksandra Poczkaj, Natalia Kułach \& Stanisław Szala}

Correction to: Scientific Reports https://doi.org/10.1038/s41598-018-25688-y, published online 09 May 2018

The Acknowledgements section in this Article is incomplete.

“This work was performed within the framework of the project No. UMO-2015/17/N/NZ4/02738. This work was supported by equipment bought for the purposes of the Project: "Silesian BIO-FARMA Center for Biotechnology, Bioengineering, and Bioinformatics" co-financed by European Regional Development Fund within the framework of Innovative Economy Operational Programme 2007-2013."

should read:

"This work was performed within the framework of the project No. UMO-2015/17/N/NZ4/02738 financed from the funds of National Science Center. This work was supported by equipment bought for the purposes of the Project: "Silesian BIO-FARMA Center for Biotechnology, Bioengineering, and Bioinformatics" co-financed by European Regional Development Fund within the framework of Innovative Economy Operational Programme 2007-2013."

\begin{abstract}
(c) (i) Open Access This article is licensed under a Creative Commons Attribution 4.0 International License, which permits use, sharing, adaptation, distribution and reproduction in any medium or format, as long as you give appropriate credit to the original author(s) and the source, provide a link to the Creative Commons license, and indicate if changes were made. The images or other third party material in this article are included in the article's Creative Commons license, unless indicated otherwise in a credit line to the material. If material is not included in the article's Creative Commons license and your intended use is not permitted by statutory regulation or exceeds the permitted use, you will need to obtain permission directly from the copyright holder. To view a copy of this license, visit http://creativecommons.org/licenses/by/4.0/.
\end{abstract}

(C) The Author(s) 2020 